REPRINT AND GIRCULAR SERIES OF THE

\title{
NATIONAL RESEARGH
}

\section{COUNGIL}

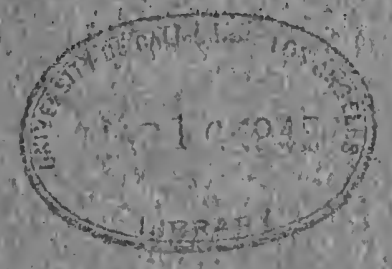

THE USEFULNESS OF ANALYTIC ABSTRACTS

By GORdON S. FULCHER

CORNING GLASS WORKS

Reprinted from Science, Vol. LVI, No. 1459,

Pages 678-680, December 15, 1922. 


\section{Announcement Concerning Publications \\ of the \\ National Research Council}

\section{The Proceedings of the National Academy of Sciences}

is partly supported by the National Research Council which is represented officially on its Editorial Board and Executive Committee. It is open for the publication of papers to members of the National Research Council on the same terms as to members of the National Academy of Sciences.

Subscription rate for the "Proceedings" is $\$ 5$ per year. Business address: Home Secretary, National Academy of Sciences, Smithsonian Institution, Washington, D. C.

\section{The Bulletin of the National Research Council}

presents contributions from the National Research Council, other than proceedings, for which hitherto no appropriate agencies of publication have existed.

The "Bulletin" is published at irregular intervals. The subscription price, postpaid, is $\$ 5$ per volume of approximately 500 pages. Numbers of the "Bulletin" are sold separately at prices based upon the cost of manufacture.

The Reprint and Circular Series of the National Research Council

renders available for purchase, at prices dependent upon the cost of manufacture, papers published or printed by or for the National Research Council.

Orders for the "Bulletin" or the "Reprints and Circulars" of the National Research Council, accompanied by remittance, should be addressed: Publication Office, National Research Council, I 701 Massachusetts Avenue, Washington, D. C. 
Reprinted from Science, pages 678-680, Vol. LVI, No. 1459 , December $15,1922$.

\section{THE USEFULNESS OF ANALYTIC ABSTRACTS}

THE various ways in which preliminary abstracts should be of service to scientific readers were pointed out about a year ago', but whether such abstracts as actually prepared and published would be worth while could be determined only by experiment. This has been done. After analytic abstracts had been appearing in the Astrophysical Journal and the Physical Review ${ }^{2}$ for over two years the following return post-eard questionnaire was sent by the chairman of the Division of Physical Seiences of the National Research Council to each reader, with the request that he underscor'e in each parenthesis the word or words which represent his answer to the question implied:

I look through (the Astrophysical Journal, the Physical Review) regularly. Before reading the articles, I read the abstracts (always, usually, sometimes, scldom, nerer). Instead of reading the articles, I read the abstracts in (many, some, few, no) eases. The abstracts have helped me understand the articles in (some, few, no) cases. The abstracts have proved useful in locating information in (some, few, no) cases. I read the subtitles in the abstracts first (sometimes, never). I find the subtitles of value as an index of the

1 "Scientific Abstraeting" by G. S. Fulcher, Science 54, 291, September 30, 1921.

2 The preliminary abstracts in the Physical Rcview are called "Synopses" to distinguish them from the abstracts of papers presented at meetings which are printed in connection with the proceedings of the Society. 
abstract (sometimes, never). The abstracts in general give (too much, too little, about enough) information. I think they should be continued (yes, no).

I have the following suggestions to make:

Replies were received from 805 readers, including 83 reader's of the Astrophysical Journal, 502 readers of the Physical Review, and 220 readers of both. Although the answers from the three groups have been tabulated separately, the results are so nearly the same for each that only the results for all readers, that is, the percentages of all readers answering each question in each alteruative way, will be given here. Since some replies are incomplete, the sum of the percentages is usually less than 100 .

1. How frequently are the abstracts read before the articles?

$\begin{array}{lll}\text { always } & \text { by } & 41.9 \text { per cent. of readers. } \\ \text { usually } & \text { by } & 45.9 \text { per cent. of readers. } \\ \text { sometimes } & \text { by } 9.9 \text { per cent. of readers. } \\ \text { seldom } & \text { by } 2.1 \text { per cent. of readers. } \\ \text { never } & \text { by } 0.2 \text { per cent. of readers. } \\ & \\ & \end{array}$

2. How many abstracts are read instcad of the articles?

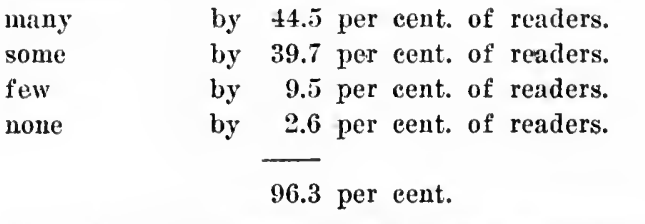

3. How many abstracts helped in understand. ing the articles?

some helped $\quad 58.1$ per cent. of readers.

few helpel $\quad \mathbf{1 7 . 7}$ per cent. of readers.

none helped $\quad 11.8$ per eent. of readers.

87.6 per ceut. 
4. How many abstracts have proved useful in locating information?

some useful to 59.3 per cent. of readers.
few useful to 16.6 per cent. of readers.
none useful to 11.4 per cent. of readers.

87.3 per cent.

5. Should the abstracts be continued?

yes $\quad 92.8$ per cent. of readers.

но 4.0 per cent. of readers.

96.8 per cent.

Since the abstracts are read, always or usually, by 88 per cent. of the readers; are read instead of many of the articles by 45 per cent.; and have heen. found helpful in other ways by 59 per cent., they have evidently proved of decided value. In what ways? According to the testimony of the readers: "They are great time savers"; "They frequently give all information necessary about the articles"; "They double a man's range of reading." Moreover, the abstracts have been copied verbatim in Science Abstracts and have thus reduced the labor of preparing that abstract journal by ten per cent. The abstracts have therefore to some extent fulfilled their purpose of saving the time of scientific men.

How about other sciences? Are astronomy and physies essentially different from chemistry, botany, zoology, geology, physiology, etc., in their methods of disseminating seientific information? If 93 per cent. of the readers of these astronomical and physical journals find that preliminary abstracts are useful to them, would not the great majority of other scientific readers also find such abstracts useful? The responsibility resting upon the editors of other scientific journals is elear.

Now as to the nature of the abstracts which should be provided. The abstracts which have 
been appearing in the Astrophysical Journal and Physical Review are of the analytic type developed by the National Researeh Council. ${ }^{3}$ They aim to give a complete description and adequate summary of the results reported in each article. The replies to the question:

6. Is the amount of information given, in general, about enough, too little, or too much? about enough $\quad 79.8$ per cent. of readers. too little $\quad 6.7$ per cent. of readers. too much $\quad 4.8$ per cent. of readers.

91.3 per cent.

these replies indicate that the abstracts, averaging from 5 to 6 per cent. of the articles, have been of about the right length, and it is not believed they could be made much shorter without considerably decreasing their value.

A distinctive feature of the abstracts is that they contain italicized subtitles which give the rarious subjects involved more completely and precisely than in general it is possible for the author's titles to do. One purpose of these subtitles is to enable a reader who is not interested in the subject indicated by the author's title to determine by glancing through the subtitles whether something of interest to him has not been ineidentally included. Until readers became accustomed to these subtitles, however, it was to be expected that most readers would consider them more of an aunoyance than a help; but the following replies show that a surprising percentage of the readers have already found the subtitles useful:

\%. Do you ever read the subtitles in the abstracts first?

sometimes

64.1 per eent. of readers.

never

17.5 per eent. of readers.

81.6 per cent.

3 Deseribed in "Scientifie Abstracting" referred to abore. 
8. Do you ever find the subtitles of value as an index of the abstract?

sometimes

never
63.0 per cent. of readers.

12.7 per cent. of readers.

75.7 per eent.

Since the subtitles also serve the purpose of assisting in the compilation of a complete subject index and tend to insure more complete abstracts, it is believed this feature should be retained. Only three readers definitely objected to the form of the analytic abstracts.

It is the practice of both these journals to submit all authors' abstracts to an abstract editor to be revised or if necessary rewritten, in conformity with the standards adopted. While a few authors have objected to having their abstracts "robbed of individuality," a number of readers specially called attention to the importance of having the abstracts edited so that a uniform standard might be maintained. It can safely be affirmed that since most authors are inexperienced in writing $a b$ stracts and also differ widely in their ideas of the function of the abstract, authors' abstracts if not thoroughly edited are sure to fall far short of rendering the service which preliminary abstracts should render, even if detailed instructions are furnished. But after the edited abstracts begin to appear regularly, they gradually establish a standard to which authors will conform more and more closely as time goes on, and therefore the amount of editing required will become less and less.

Finally, mention should be made of the suggestion of several readers that larger type be used for the abstracts than has been the custom. Since more people read the abstracts than read the articles, it would seem obvious that the type of the abstracts shonld be at least as large as that of the articles. 
It should not be long before all scientific journals, in fulfilment of their duty toward their readers, provide carefully prepared preliminary abstracts of their scientific articles. There can no longer be any doubt of the value of such abstracts. It remains only to overcome the practical obstacles to the introdnction of the new policy.

In conclusion we desire to express our thanks to the 805 readers whose cooperation gave us the information herewith reported.

Gordon S. Fulcher

CORNing Glass Works 
Digitized by the Internet Archive in 2007 with funding from Microsoft Corporation 



\section{The National Research Council}

Membership and Organization.-The National Research Council is a coöperative organization of scientific men of America, including also a representation of men of affairs interested in engineering and industry and in the "pure" science upon which the applied science used in these activities depends. Its membership is largely composed of accredited representatives of about seventy-five national scientific and technical societies.

The Council was established at the request of the President of the United States, under the Congressional charter of the National Academy of Sciences, to coördinate the research facilities of the country for work on war problems involving scientific knowledge. In 1918, by Executive Order, it was reorganized as a permanent body. Although partly supported during the war period by the government and primarily devoted at that time to its activities, the Council now derives all of its financial support from other than governmental sources and is entirely controlled by its own representatively selected membership and democratically chosen officers. It maintains, however, a close coopperation with government scientific bureaus and their activities.

Purpose-The Council is neither a large operating laboratory nor a repository of funds to be given away to scattered scientific workers or institutions. It is rather an organization which, while clearly recognizing the unique value of individual work, hopes especially to bring together scattered work and workers and to assist in coördinating scientific attack in America in any and all lines of scientific activity. Its essential purpose is the promotion of scientific research and of the application and dissemination of scientific knowledge for the benefit of the national strength and well-being.

\section{Research Fellowships}

The Council maintains, with the financial assistance of the Rockefeller Foundation and General Education Board-to the amount of one million dollars, to be expended during a period of five years-two series of advanced fellowships.

Fellowships in Physics and Chemistry.-Candidates must already have made the doctor's degree or have equivalent qualifications and have demonstrated a high order of ability in research. Address applications to Secretary, Fellowships Board, National Research Council, Washington,D.C.

Fellowships in Medicine.-Both graduates in medicine and doctors of philosophy in one of the sciences of medicine, or in physics, chemistry, or biology are eligible for these fellowships. Address applications to Chairman, Division of Medical Sciences, National Research Council, Washington, D. C. 


\section{RESEARCH \\ INFORMATION SERVICE}

$A_{\text {a Clearing-House for }}^{\mathrm{T}}$ Scientific and Technological Information.

If you have an informational need, write

\section{INFORMATION SERVICE NATIONAL RESEARCH COUNCIL WASHINGTON, D. C.}

